The average half right carcass weight was $36.8 \mathrm{~kg}$ for $L B(\mathrm{~N}=\mathrm{I} 6), 35.7 \mathrm{~kg}$ for $L F(\mathrm{~N}=\mathrm{I} 6)$ and $36.6 \mathrm{~kg}$ for $P(\mathrm{~N}=15)$. Carcass length from the anterior edge of pubis to the first rib was $78.9 \mathrm{~cm}(L B), 83.6 \mathrm{~cm}(L F)$ and $73.2 \mathrm{~cm}(P)$ respectively.

Large differences were found between breeds, Landrace Français showing the poorest conformation. In spite of a greater carcass length, the Landrace Belge pigs were quite similar to the Pietrain in the middle of the back (from the 8th thoracic vertebra to the last lumbar vertebra), but had poorer development in the forepart of the back and in the quarter.

When corrected for backfat thickness, the Pietrain breed had the best objective scoring of conformation. It is thus suggested that carcasses of the three types are of different commercial interest and that the high-muscling character of $L B$ and $P$ corresponds to different morphological types, and probably to various genetic conditions for muscle development.

\title{
ÉTUDE EN BILAN AZOTÉ ET COMPOSITION CORPORELLE DES PORCS MÂLES ENTIERS OU CASTRÉS DE RACE « LARGE WHITE »
}

\author{
B. DESMOULIN, M. BONNEAU et D. BOURDON \\ Station de Recherches sur l'Élevage des Porcs, \\ Centre national de Recherches zootechniques, I. N. R. A., \\ 78350 Jouy en Josas
}

\section{RÉSUMÉ}

Douze porcs mâles entiers ou castrés de race Large White ont été soumis, à 40 et $70 \mathrm{~kg}$ de poids vif, à deux périodes de bilans en cage de digestibilité, en alternance avec les périodes de séjour en porcherie d'engraissement.

Au stade final d'abattage $(97 \mathrm{~kg}$ ) la dissection des carcasses permet les mesures de composition corporelle. Le régime maïs-soja distribué, était additionné (ou non) d'une substance à effet antioxygène : le Butyl-Hydroxytoluène ou BHT. Les résultats concernent l'influence de la castration et celle de l'additif alimentaire sur les différents critères.

La castration des porcs mâles entraîne une réduction de I 4 p. roo de l'efficacité alimentaire globale sans variations notables des performances de croissance. Au stade de $40 \mathrm{~kg}$, les bilans azotés sont comparables chez les mâles entiers ou castrés qui fixent respectivement I 20 et I $24 \mathrm{~g}$ de protéines/jour. Par contre, à $70 \mathrm{~kg}$ de poids vif, les mâles entiers fixent $\mathrm{I} 44 \mathrm{~g}$ de protéines/jour pour $123 \mathrm{~g}$ seulement chez les castrats. Les différences sont attribuées à une épargne de $25 \mathrm{p}$. roo de l'excrétion urinaire d'azote chez le mâle entier, alors que l'utilisation digestive des constituants est meilleure chez les mâles castrés.

L'addition de $\mathrm{BHT}$ au régime est sans effet sur le bilan azoté. Elle entraîne par ailleurs une augmentation de 40 à $50 \mathrm{p}$. Ioo de l'excrétion urinaire d'énergie, notamment en seconde période de collecte. 
Au stade final d'abattage, la composition des carcasses n'est pas influencée par l'addition de BHT, alors que le poids des foies est accrû de $15 \mathrm{p}$. Ioo chez les mâles entiers et de 40 p. Ioo chez les mâles castrés. Les fortes différences de composition tissulaire liées à la castration se caractérisent par une réduction de Io p. Ioo des masses musculaires et une augmentation de 20 p. Ioo des poids de graisses. La quantité de peaux étant plus élevée de $20 \mathrm{p}$. Ioo chez les mâles entiers, une partie de l'excédent des protéines fixées par rapport aux mâles castrés concerne donc les fractions tissulaires de moinđre valeur commerciale. La discussion des résultats porte sur la signification des critères de bilans azotés établis sur de courtes périodes.

\title{
SUMMARY
}

\author{
NITROGEN BALANCE STUDY AND BODY COMPOSITION \\ OF ENTIRE OR CASTRATED MALE PIGS OF THE LARGE WHITE BREED
}

Twelve entire or castrated male pigs of the Large White breed were submitted, at a live weight of 40 and $70 \mathrm{~kg}$, to two nitrogen balance periods in digestibility cages, alternately with periods of feeding in pig fattening houses.

The animals were slaughtered at a weight of $97 \mathrm{~kg}$, the carcasses cut and the body composition measured. The maize-soyabean diet used included (or not) a substance with antioxygen effect : butyl-hydroxytoluene or BHT. The results obtained concern the effect of castration and that of the food additive on the different criteria studied.

Castration of male pigs led to a I4 p. Ioo reduction of total feed efficiency without notable variation of growth performances. At $40 \mathrm{~kg}$ live weight, the nitrogen balances were comparable in entire or castrated males, retaining $\mathrm{I} 20$ and $\mathrm{I} 24 \mathrm{~g}$ of protein/day, respectively. On the other hand, at $70 \mathrm{~kg}$ live weight, the entire males retained $144 \mathrm{~g}$ of protein/day versus only $\mathrm{I} 23 \mathrm{~g}$ in the castrated animals. The differences were related to a $25 \mathrm{p}$. Ioo sparing of the urinary excretion of nitrogen in the entire males, whereas the digestibility of the constituents was better in the castrated males.

The addition of BHT to the diet did not affect the nitrogen balance. In addition, it resulted in a $40-50 \mathrm{p}$. Ioo increase of the urinary excretion of energy, especially in the second period of collecting.

In the last growth phase before slaughter, the carcass composition was not affected by the addition of BHT, whereas the live weights increased by $15 \mathrm{p}$. Ioo in the entire males and by $4^{\circ} \mathrm{p}$. Ioo in the castrated males. The large differences in the tissular composition related to castration were characterized by a Io p. Ioo reduction of lean masses and a $20 \mathrm{p}$. Ioo increase in the weight of fats. The amount of skin being $20 \mathrm{p}$. Ioo higher in the entire males, part of the proteins retained in excess as compared to the castrated males, therefore represented tissular fractions of poorer commercial value. The signification of nitrogen balance criteria established over short periods is discussed. 